\title{
CREATIVITY AS A SUCCESS FACTOR IN PROMOTIONAL ASPECT OF PRODUCTS IN PRODUCTION COMPANIES
}

Rajan Arapi $^{1}$

\begin{abstract}
The creativity, as a general concept, is considered an activity which gives birth to something new that did not exist before. This topic can be affected also from the philosophical and physiological point of view. The psychology of creativity studies "Psychological Mechanism" from which stem the actions of creativity.

In promotion terms there are different points of views that are considered to be an integral part of creativity in the field of product advertising. First, there are people who estimate if the promotion is creative whereas on the other side the effect only in cases where you succeeded to sell the product. Second, there are people who consider their creativity or design of the promotion as their originality artistic or esthetical value.

What constitutes the creativity in one of the elements of the promotion is distinguishing and entertaining idea of being different from the others, but the creative message must be short and clear. Advertisements or promotional campaigns that are creative rarely fail to transmit their message to the public consumer. In this case, the entire team that is engaged in planning and developing the promotional campaign must balance their attitudes around the creative idea.

This research presents the development of ideas and designs of creative promotional spaces for Kosovar companies in cases of the advertisement of their new and existing products in the market. The methodology of this research will be descriptive and comparative between a few manufacturing Kosovar companies.
\end{abstract}

JEL Classification Numbers: M30, M37, M39, DOI: http://dx.doi.org/10.12955/cbup.v3.576

UDC Classification: 658.8

Keywords: Promotion, Advertise, Creativity, Consumer, Company

\section{Introduction}

Creativity is the most common phenomenon of advertising. The fact that an advertisement must be created and people are the ones who create and realize them, the success of this whole process stems from creativity. The attention that must be paid to the creative concept is a challenge in itself for the creator; meanwhile the marketing companies which in this case develop advertisements base their reputation on creativity. The most well identified methods of developing, especially when it comes to creativity in a group is: the brainstorming method, catalogue of creative ideas, choosing someone else's idea, analogy and metaphor, cohesion (learning from the strange, from other reference points). It is possible that creativity can be facilitated when there is an encouraging environment that changes and reinforces them. Academic debates, relate the creativity with a few philosophical and psychological aspects which have different placements in different historical eras. Plato said that things in this world are simply the shadows of ideas that live in the mental world. Because the human mind thinks through figures, therefore, does not reach to the clear and pure ideas; there is a need for imaginative intervention as the highest spiritual ability. It uses images which are "clothes" of pure ideas of mental world. It is a spiritual organ, and organ of metamorphosis and renewal (Wordpress, 2010). Depending on the nature of the business, creative thoughts and ideas are almost necessary. The same thing is applicable also for other members of the team that fulfil the advertisement or promotional campaigns. Their duty is to write the script and proportional messages, compile structures, and realize the advertisement-always making sure that the wanted message is effectively transmitted. The situations that companies face are almost different every time, especially for the marketing team. With each realization or project these teams have, the creative access is needed. After all, through this hard work there is the question whether there is any rule on which these teams should be supported by. Sneiden (2001) argued that the only clear and correct answer related to advertisement is that there are no rules. There is no formula; there is no common way to come to realization. If any Creative team of

\footnotetext{
${ }^{1}$ Rajan Arapi, University Haxhi Zeka, Kosovo, rajan.arapi@unhz.eu
} 
advertisement comes into a conflict of either ideas or realization, the creative talents of this field will give their solution in accordance with their perception and personal ideas.

\section{The effect of creative promotion and product development}

The best advertisements are not simply creative, they sell the product. Creativity is not enough. An advertisement is memorable through art, it creates a certain feeling to the audience, but even these are not enough. A good advertisement should deliver the correct item to make people want it, believe in it and buy the product. There are combinations of idea creativity, art, and the right message to make an almost perfect advertisement. Even the elements of an excellent advertisement should be renewed or they will not yield the expected results. Such elements could be: characters, slogans or types of messages. Creativity in advertisement, in most of the cases, contains a dose of risk which in this case should be held by the clients themselves who are the people who ordered the advertisement or a promotional campaign. In this case, advertisement agencies that design advertisement and believe in their creativity should be capable of convincing the client to transfer the risk for the advertisements that withhold in it a big amount of creativity. According to Saffert (2013), the promotional campaigns that appear with an over average amount of creativity transmit a higher impact on sales rather than other less creative alternatives.

A number of companies cannot disagree with the fact that a risky advertisement is, at the same time effective, because of the amount of creativity. The managers of these companies prefer advertisements that highlight the characteristics and advantages of the products, which in this case are the reasons for the customer to buy the product. The ones that conceptualize advertisements have different methods of creating them. One of the methods is creating a connection between a brand directly with the profit or one definition. Meanwhile, Leo Burnett, (Burnett, 1998), one of the famous creators of advertisements in the world, prefers to create characters that express the virtuous personality of the products. In this regard, we can refer to the famous cowboy of the Marlboro Company as an example.

The purpose of an advertisement should not be to tell facts around the product, rather it should sell on a choice or a dream. An advertisement should address the consumers' aspirations. This is done by Harley Davidson, Armani, and Western Union, etc. A Harley Davidson is not advertised as a motorcycle that works better than the others, but as a possibility for people to have a particular lifestyle and to feel free like a hero. Charles Revson, the founder of beauty products "Revlon" said: "In our factory, we produce lipstick." "In our advertisement we sell hope." For people not to doubt the advertisement that promises the realization of a dream, the advertisement should be executed with the elements mentioned earlier: creativity, art, and the right message. Very few people would believe someone who goes public on television and says that their product is a solution for every single problem. Why are most of the advertisements not creative? Let's take a look at car advertisements. In $90 \%$ of the advertisements on TV, there is a car driven through the beautiful rural area and empty streets at a very high speed-much like an advertisement broadcasted in Albania or Kosovo. That is true for most of the places where the advertisement is just taken as a final product from the producer. How can an advertisement like that be productive? We do not have very beautiful roads; actually our streets are full of pits. There are no such streets that are empty as shown in the advertisement. Furthermore, the maximum speed that is allowed in the rural area is $60 \mathrm{~km}$ per hour; people cannot drive at $120 \mathrm{~km}$ per hour like in the advertisement. The conclusion is that such advertisements are wasteful material and a waste of the customer's time. The lack of creativity in advertisements does not come from the advertisement agencies, but from the companies themselves. Kotler (1999) argued that if a company sees that the advertisement agency they hired to create the advertisement has created something a little more "wild" or " breaks the taboo," they would ask to have it altered to become more "normal" because they are afraid of the public reaction. This can happen when a company has 
been paid, but also it could happen to the employees of the enterprise. Companies should raise a very important question before they advertise. Will the advertisement make clients more content rather than using the money in producing higher quality product, improving client service, or creating a stronger brand experience? The answer to this question is never simple. On one side, the better the product the less we will need to spend on advertising because content customers are the best advertisement; loyal customers make the advertisement unnecessary. However, there are also people who blindly believe in advertisements. Britt (1970) stated, "to do business without advertisement is the same as stepping on the eye of a girl in the dark. You know what you are doing, but the other doesn’t know that.”

\section{Development of creative strategy in terms of mix promotion}

Advertisement or creative promotion refers to the fact that companies with the realized advertisement have targeted their specific clientele. In this case, companies do not address everyone, but only the clientele that they have previously targeted. To have an attractive advertisement or promotional campaign, the companies should know their clientele very well. When we say "know the clientele," it often lead to more problems because realistically the representatives of the companies and the carriers of the advertisement have never met any of the clients. In fact, the client will be more attractive to the service or the product.

According to Haxhiaga (2013), the creative advertising is a terminology that is widely used today, especially in the United States. The core of this kind of advertisement is not the sales, but it is education, information, and creation of one's own audience, public awareness, and clientele.

Most of the promotional campaigns or advertisements as a specific form are a part of an Integrated Marketing Communication (IMC). In this case, the promotional campaigns and advertisements should withhold the message and should concentrate on one idea because they may be broadcasted in different media or can be executed in a different mix of promotion forms. In this case, it is very important that the theme of the promotional campaign contains a clear idea because that is considered the core message that will be transmitted through every applicable form that the companies deploy.

Planning for a promotional campaign should be short—around a year long. Furthermore, the themes of the campaign can also be analyzed and determined for longer periods of time. Belch \& Belch (2007) explained that the reason why these plans are short is because of the possible changes that may happen in the market and the competition. Despite what was stated above, promotional campaigns for a lot of well-known companies (e.g. Philip Moris, General Mills, etc.) remain the same.

Creative strategies are based on some factors that include:

- identification of the targeted public,

- base problem,

- the issue and the possibility where the advertisement needs to be directed,

- the main idea of sales or key profit from this process,

- other information's needed to be included in the advertisement.

Belch \& Belch (2007) said that after these factors are determined, with the support of creative strategies, the main message should be determined and also shown clearly in their appearance. This entire process is identified based on one document—platform of the advertisement or promotional campaign that the manager of the marketing has compiled earlier. Creative strategies of advertisement, designed by the experts in marketing, often lead to gift giving in case of a purchased product. This fact is confirmed by many researches and is also used today as a form of promotion by Kosovo companies. One single product can trigger a few different emotions for the client. For example, a special promotion offered as a surprise gift from the store makes the buyers more likely to buy the product the 
next time, which is more effective than a blanket offer given to everyone. According to Tsiron \& Laran (2014), this method raises the number of sales for private businesses and their likeliness to attract those who would like to shop there. On the other hand, if one product triggers fewer emotions, but is more popular, it will have other effects on the buyers. For example, if an electric vacuum cleaner is accompanied by an unknown gift, the buyers have 50 percent more chance of buying the offered product rather than when they know what the actual accompanying gift is. The effectiveness of these creative promotions depends directly on the feeling created for the buyer. The emotions created from the submitted offer press the buyer to make a decision of whether he or she should buy the product. In marketing, it is never a matter of one buyer, but millions of them; therefore, the researchers are researching to find the common trigger to manipulate the feelings of millions of consumers for their own benefits and sales in the global markets.

\section{Product promotional methods applied by the manufacturing companies in Kosovo}

"There is no such thing as good or bad advertisement." This is very well known quote in the advertising world and it is true to some extent, but when the advertisement is special and sends the message to the client then the success is undisputed. The types of promotions that manufacturing companies in Kosovo apply these days are realized in different places and locations, depending on the case and the market situation. These are separated into Indoor Sampling and Outdoor Sampling (the indoors and outdoors execution).

\section{Taste the Product}

This promotional form is regular within the framework of campaigns that companies organize after placing new products in the market. This form of promotion, includes direct contact between the product and the consumer. Consumers in this case are given the opportunity to appraise the product by tasting it, seeing a close up of the packaging and all the other characteristics it possesses.

\section{Extra positioning of the products in the main areas of the shops}

This kind of promotion is often used as the company campaign that manufacturers in Kosovo organize with the goal of creating a center of attention. This is done mainly in big shops, such as supermarkets and hypermarkets. This kind of promotion is organized mainly during different holidays, such as end of year holidays or company anniversaries, etc.

\section{Distributing informative flyers}

Such promotional activities are an inseparable part of most of the companies that operate in the territory of Kosovo, but their positive effect is rare because they do not carefully apply their promotional form. This kind of promotion is typical in most of the manufacturing companies. Companies use this kind of promotion mainly when they have something new or innovative, either when adding a product or when there are any sales, which are frequent and quite attractive.

\section{Secondary sample}

This promotion involves giving a free product sample, such as buy 6 get 1 free (e.g. buy a pack of juices and get a 2-liter bottle for free).

\section{Open air promotions}

This is simply giving out products for free. It is very often seen that the new product put out in the market require the attention of a big crowd who is considered potential consumer. Open air spaces, main squares of cities, locations where people like to spend their weekend, and other frequented places can be considered ideal locations for sensational promotions. This kind of promotional activity makes the product the center of attention. 
CBU I NTERNATIONAL CONFERENCE ON I NNOVATION, TECHNOLOGY TRANSFER AND EDUCATION

\begin{tabular}{|c|c|c|c|}
\hline \multicolumn{4}{|c|}{ Conceptualizations of ad creativity } \\
\hline Source & Divergence factor(s) & Relevance factor(s) & Effectiveness factor(s) \\
\hline $\begin{array}{l}\text { Jackson and } \\
\text { Messick (1965) }\end{array}$ & $\begin{array}{l}\text { Unusualness } \\
\text { (i.e. infrequent) }\end{array}$ & $\begin{array}{l}\text { Appropriateness (i.e. } \\
\text { fits its context), } \\
\text { Condensation (i.e. } \\
\text { warrants repeated } \\
\text { examination) }\end{array}$ & $\begin{array}{l}\text { Transformation (i.e. } \\
\text { forces us to see } \\
\text { reality in a new way) }\end{array}$ \\
\hline $\begin{array}{l}\text { Sobel and } \\
\text { Rothenberg (1980) }\end{array}$ & $\begin{array}{l}\text { Originality (i.e. } \\
\text { newness) }\end{array}$ & Value (i.e. worth) & \\
\hline $\begin{array}{l}\text { Besemer and } \\
\text { Treffinger (1981); } \\
\text { Besemer and } \\
\text { O'Quinn (1986) }\end{array}$ & $\begin{array}{l}\text { Novelty (i.e. } \\
\text { newness), } \\
\text { Elaboration and } \\
\text { synthesis (i.e. } \\
\text { stylistic details) }\end{array}$ & $\begin{array}{l}\text { Resolution (i.e. } \\
\text { functionality)/ } \\
\text { Appropriateness } \\
\text { (i.e. solves problem) }\end{array}$ & \\
\hline Amabile (1983) & Novelty & $\begin{array}{l}\text { Appropriate, useful, } \\
\text { valuable }\end{array}$ & \\
\hline $\begin{array}{l}\text { Haberland and } \\
\text { Dacin (1992) }\end{array}$ & $\begin{array}{l}\text { Originality (i.e. } \\
\text { deviates from } \\
\text { expectations) }\end{array}$ & $\begin{array}{l}\text { Meaningfulness (i.e. } \\
\text { conveys meaning), } \\
\text { Condensation (i.e. } \\
\text { warrants repeated } \\
\text { examination) }\end{array}$ & $\begin{array}{l}\text { Reformulation (i.e. } \\
\text { modify brand } \\
\text { attitude) }\end{array}$ \\
\hline $\begin{array}{l}\text { Thorson and Zhao } \\
\text { (1997); Wells (1989) }\end{array}$ & $\begin{array}{l}\text { Originality (Novelty } \\
\text { of the creative } \\
\text { product) }\end{array}$ & $\begin{array}{l}\text { Meaningfulness/ } \\
\text { appropriateness/ } \\
\text { relevance } \\
\text { (personal concerns } \\
\text { or interests) }\end{array}$ & $\begin{array}{l}\text { Impact (stopping } \\
\text { power, connections } \\
\text { to ad) }\end{array}$ \\
\hline Tellis (1998) & $\begin{array}{l}\text { Divergent (different } \\
\text { from what is } \\
\text { currently done) }\end{array}$ & & $\begin{array}{l}\text { Productive } \\
\text { (redeeming value, } \\
\text { contributes to } \\
\text { brand's welfare) }\end{array}$ \\
\hline $\begin{array}{l}\text { Duke (2000); Duke } \\
\text { and Sutherland } \\
(2001)\end{array}$ & Imaginativeness & $\begin{array}{l}\text { External confluence } \\
\text { (similarity with similar } \\
\text { products); Internal } \\
\text { confluence (similarity } \\
\text { across executions } \\
\text { within a campaign) }\end{array}$ & \\
\hline
\end{tabular}

Source: Yang (2004)

\section{Promotional actions in the forms of $1+1,4+2$, and $3+1$ free}

These are actions taken by companies that organize them once a year and last no longer than two weeks. These kinds of promotions are usually organized at the end of the year to somehow reward the 
customers and also to get the products on as many of the customers' dining tables as possible for the end of year festivities. This is considered productive advertising.

\section{Promotion of the products through different e-marketing formats}

Aside from the classic way of advertising through companies' websites and other fan pages, the promotion of juices in flash clips in .jpg format, publication of advertising in video format in different channels online present more opportunity to advertise. The special promotional activities that manufacturing companies undertake through E-Marketing include newsletter where companies publish their own monthly newspaper or online catalogue with useful information about their products and details about their ingredients.

\section{Conclusion}

Being creative undoubtedly is directly connected with originality that companies have on building the ideas for their product advertisements in the written media, electronic forms, and other formats mentioned above. Although in Kosovo, Marketing as a concept is considered new and delayed. In the past years, it starting to accelerate the steps to be on the same pace with the advertising trends in the world. The opening of many marketing agencies and promotion of employees abroad has raised the level of creativity and resulted in improvement of advertisements and promotional campaign quality from companies in Kosovo. It is worth mentioning that the self-awareness of companies in Kosovo to pay attention to Marketing, specifically in advertising as well as allocating monthly budget for this very important field, has intensified the concentration and competition in the field of advertisement and promotional campaigns. It is also worth mentioning that the main concentration of creative advertisement right now in Kosovo is shown by telecommunication companies and also manufacturers who have dedicated a high percentage of profit to conducting market research with emphasis on the realization and intensive publications of promotions in the media and other attractive indoor and outdoor forms. In terms of understanding creative advertisement, which often holds imaginative ideas and is also not easily understood by the public, companies shift their concentration to consumers with a positive belief in influencing consumers to purchase more products.

\section{References}

Britt, S. H. (1970). Psychological principles of Marketing and Consumer Behavior. New York: Wiley Unknown Binding.

Burnett, L. (1998). Funding Universe. Retrieved January 2014, from http://www.fundinguniverse.com/companyhistories/leo-burnett-company-inc-history/

Belch, G. E., \& Belch, M. A. (2007). Advertising and Promotion. Boston: McGraw-Hill Irwin.

Haxhiaga, E. (2013, September). elvirahaxhaga. Retrieved January 23, 2015, from http://elvirahaxhiaga.com/2013/09/09/trifaktet-qe-vendosin-per-egzistencen-e-biznesit-tend-online/

Kotler, P. (1999). How To Create, Win, and Dominate Markets. New York: A Division of Simon \& Schuster Inc.

Saffert, W. R. (2013, June). Harvard Business Review. Retrieved December 2014, from https://hbr.org/2013/06/creativity-inadvertising-when-it-works-and-when-it-doesnt

Sneiden, H. (2001). Advertising Pure and Simple. New York.

Tsiron, M., \& Laran, J. (2014). The strategy of giving gifts in marketing, sales increases. Miami: Business Administration, University of Miami.

Wordpress (2010, February). Retrieved December, 2014, from http://dituri.wordpress.com/2010/02/22/kreativitetiimagjinata-krijuese/

Yang, R. E. (2004). Examining the role of Divergence, Marketing Theory 4:31. Toward a general theory of creativity in advertising. Sage Publications. 